\title{
Prognostic Relevance of hMLH1, hMSH2, and BAX Protein Expression in Endometrial Carcinoma
}

\author{
Gloria Peiró, M.D., Joachim Diebold, M.D., Doris Mayr, M.D., Gustavo B. Baretton, M.D., \\ Rainer Kimmig, M.D., Michael Schmidt, M.D., Udo Löhrs, M.D. \\ Institute of Pathology (GP, JD, DM, GBB, UL), Department of Gynecology and Obstetrics (RK), and Tumor \\ Registry (MS), Ludwig-Maximilians University Munich, München, Germany
}

Endometrial carcinoma is the most common gynecologic malignancy in perimenopausal and postmenopausal women. A role of mismatch repair genes, like hMLH1 and hMSH2 in their pathogenesis, has been suggested. Loss of their function leads to the accumulation of replication errors (mutator phenotype), which are responsible for further mutations in genes with microsatellite sequences in their coding region, such as Bax. We analyzed the expression of hMLH1, hMSH2, and Bax genes in 89 formalin-fixed paraffin-embedded endometrial carcinomas. The immunostains were scored with regard to percentage of positive tumor cells $(0 \%$, $<10 \%, 10$ to $50 \%,>50 \%$ ), and relative staining intensity $(1+, 2+, 3+)$. The staining results were correlated with clinicopathologic features and survival. Loss of hMSH2 expression ( $0 \%$ positive cells) was observed in $1.1 \%(1 / 89)$ of the tumors; loss of hMLH1 was seen in $12.4 \%(11 / 89)$ of the cases, particularly in endometrioid tumors with mucinous differentation $(5 / 11 ; 45 \% ; P=.03)$. No significant association was found between the immunoscores and grade, stage criteria of the International Federation of Obstetrics and Gynecology (FIGO), or age of the patients. Among 11 tumors with loss of Bax expression (12.4\%), 4 had also loss of hMLH1 (4/11; $36.4 \% ; P=.017$ ). In multivariate analysis (Cox model), significantly longer survival was found for patients with tumors in FIGO Stage I-II $(P<.0001)$, endometrioid type $(P=.001)$, low grade $(P=.001)$, and absence of hMLH1 expression $(P=.027)$. Our results suggest that loss of function of hMLH1 and Bax occur in a subgroup of endometrial carcinoma. In addition to the classical prognostic factors, ab-

Copyright $(2001$ by The United States and Canadian Academy of Pathology, Inc.

VOL. 14, NO. 8, P. 777, 2001 Printed in the U.S.A.

Date of acceptance: March 30, 2001

This paper was presented in part at the annual meeting of the US Canadian division of the International Academy of Pathology in New Orleans, March 2000.

Address reprint requests to: Joachim Diebold, M.D., Pathologisches Institut der Universität, Thalkirchner Str 36; D-80337 München, Germany; e-mail: Joachim.Diebold@lrz.uni-muenchen.de; fax: 49-89-5160-4079. sence of hMLH1 expression is associated with better outcome of patients.

KEY WORDS: Bax, Endometrial carcinoma, hMLH1, hMSH2, Immunohistochemistry, Prognosis.

Mod Pathol 2001;14(8):777-783

Endometrial carcinoma (EC) is the most common gynecologic tumor in perimenopausal and postmenopausal women. Particularly at younger ages, it is within the spectrum of extracolonic malignancies associated with the hereditary nonpolyposis colorectal cancer syndrome (HNPCC; 1). Despite the current earlier detection and treatment improvement, it is still a leading cause of mortality. Significant progress is being made in elucidating the underlying molecular changes, but the clinical significance of these observations is largely not clear.

Defects in human mismatch repair (MMR) genes (hMLH1, hMSH2, hPMS1, hPMS2, hMSH3, and hMSH6) have been identified as the basis of microsatellite instability (MSI) in tumors from patients affected by HNPCC. In the majority of those tumors, germ-line mutations have been observed, predominantly in hMLH1 (on chromosome 3p21.3) and hMSH2 (on chromosome 2p21), with similar frequency (2-7). However, in sporadic tumors with MSI phenotype, somatic mutations in these genes occur only in a small proportion $(1,4,6,8-21)$.

The mutational spectrum appears to be diverse. Most of them ultimately result in the absence or synthesis of a truncated nonfunctioning protein, which is unable to maintain the replication fidelity, leading to an accumulation of errors in short repeat sequences $(4,5,9-13,22)$. Preservation of one wildtype allele is sufficient for mismatch repair activity. Therefore, inactivation of both alleles is required for tumorigenesis $(6,8)$. The recent availability of antibodies against the proteins involved in mismatch repair has made it possible to identify defects in the MMR system rapidly by immunohistochemistry (23). 
Generally, good correlation has been reported between mutations in these genes and MSI phenotype, on one hand, and absence of protein expression on the other hand. However, some exceptions have been observed $(4,8-14,18-21,23-29)$.

In sporadic EC, the reported prevalence of MSI ranges from 9 to $34 \%(24,25,29-38)$, and only a small proportion of those tumors show mutations in MMR genes $(26,34,36,39,40)$. More recently, abnormal methylation, predominantly of the hMLH1 promoter region associated with transcriptional loss, has been described as an alternative mode of gene inactivation in sporadic EC $(15,25$, $39,41,42)$ and in other neoplasms $(7,13,14,43)$.

The Bax gene, which contains microsatellite sequences in its coding region, is a target of mutations in tumors with mutator phenotype $(5,18$, $44-47)$, including EC $(25,42,48-50)$. It functions as a tumor suppressor gene because it normally promotes apoptosis (51). The cellular distribution of Bax has been studied in a number of normal and neoplastic tissues with contradictory results $(6,46$, 52-57).

The aim of the present immunohistochemical study was to examine the expression of the MMR genes hMLH1 and hMSH2, as well as Bax as a possible target gene in a series of EC. In addition, the relationship between immunoscores, clinicopathologic features, and prognosis was analyzed.

Our results suggest that hMLH1 and Bax play a role in a small subset of EC. Furthermore, absence of hMLH1 expression is associated with favorable outcome.

\section{PATIENTS AND METHODS}

\section{Patients and Tumor Samples}

Samples for the immunohistochemical analysis were obtained from 89 patients with EC, treated between 1984 and 1994 at the Department of Gynecology, Grosshadern, University of Munich. All patients underwent a total abdominal hysterectomy. Bilateral salpingo-oophorectomy and lymphadenectomy, as well as postoperative afterloading radiotherapy, was performed in nearly all patients except those with Stage IA according to the criteria of the International Federation of Obstetrics and
Gynecology (FIGO; 60; all histological grades) or FIGO Stage IB, Grade 1. Only patients with papillary serous carcinomas (PSC) or malignant müllerian mixed tumors (MMMT; in FIGO Stage IB or higher) received chemotherapy, usually with platinumcontaining protocols. Patient ages ranged from 39 to 92 years (mean, 66).

Histologic classification of the tumors was performed according to the WHO criteria for endometrial cancers $(58,59)$. Endometrioid carcinomas having at least $10 \%$ of another cell type were classified as mixed. In addition, mixed tumors with $>50 \%$ of PSC component were included in the category of pure PSC. Histologic grade and stage were assigned according to the FIGO criteria (60). Follow-up was available in $82(92 \%)$ patients (median, 2500 days).

\section{Immunohistochemistry}

Immunoperoxidase staining in formalin-fixed paraffin-embedded sections for hMLH1, hMSH2, and Bax was performed by labeled avidin-biotin complex (ABC) peroxidase-AEC (3 amino-9 ethylcarbazol) system. Two- to four-micrometer-thick sections were mounted on poly-L-lysine-coated slides (Sigma Chemical Co, St. Louis, MO), deparaffinized and rehydrated through graded alcohols to water. In Table 1 , the antibodies (Ab), clones, sources, pretreatments, working dilutions, incubation time, and localization of the immunostaining are given. hMLH1 Ab recognizes the full-length recombinant human MLH1 protein $(83 \mathrm{kD})$; hMSH2 $\mathrm{Ab}$ (clone $\mathrm{FE} \mathrm{11)} \mathrm{reacts} \mathrm{against} \mathrm{the} \mathrm{carboxy-}$ terminal region of the human MSH2 protein; and $\mathrm{Bax} \mathrm{Ab}$ is a synthetic peptide corresponding to a sequence in the amino-terminal (residues 150 to 165) of the human Bax protein.

After microwave pretreatment, endogenous peroxidase activity was blocked by incubation with $10 \% \mathrm{H}_{2} \mathrm{O}_{2}$. The Vectastain Elite Kit (Vector Laboratories, Burlingame, CA) was used as described by the manufacturer. The different primary Ab were applied and incubated. In negative controls, the first $\mathrm{Ab}$ was omitted. After a brief rinsing in Tris buffer containing $0.05 \%$ of Brij 35-Solution (Merck, Darmstadt, Germany), sections were immersed in

TABLE 1. Immunohistochemical Data

\begin{tabular}{llllcc}
\hline Antibodies & Clone & Vendor $^{a}$ & Pretreatment $^{b}$ & Dilution & Staining \\
\hline hMLH1 & $\mathrm{M}(\mathrm{m})$ & Serotec & pepsine & $1: 40$ & Nuclei \\
hMSH2 & $\mathrm{M}(\mathrm{m})$ & Oncogene & TRS9 & $1: 200$ & Nuclei \\
Bax & $\mathrm{P}(\mathrm{r})$ & Oncogene & Enhancer & Overnight & Cytopl \\
\hline
\end{tabular}

M, monoclonal; P, polyclonal; (m), mouse; (r), rabbit.

${ }^{a}$ Vendors: Serotec Inc., Raleigh, NC; Oncogene Research Products, Cambridge, MA.

${ }^{b}$ Pretreatments: Pepsine, Sigma Chemical Co., St. Louis, MO; Target Retrieval Sol high pH (TRS9), DAKO, Carpinteria, CA; Histosafe-Enhancer Linaris, Bettingen, Germany. 
3-amino-9-ethyl-carbazole substrate (Sigma, Steinheim, Germany) for 15 minutes, then, lightly counterstained with hematoxylin and mounted with Glycergel (Merck).

According to the number of positive tumor cells, the staining was semiquantitatively scored as follows: $0 \%(0),<10 \%$ (1), 10 to $50 \%$ (2), 51 to $80 \%$ (3), and $>80 \%$ (4). Intensity of the staining was also evaluated as weak $(1+)$, moderate $(2+)$, and strong $(3+)$. For each tumor case, the values of the two parameters were multiplied, resulting in scores ranging from 0 to 12 (Remmele score [RS]; 61). Tissue sections contained different proportions of immunostained nontumor cells, such a residual normal endometrium, endometrial stroma, myometrium, endothelial cells, or lymphocytes, which served as an internal positive control. Specimens in which tumor cells, as well as normal control cells, were completely negative for $\mathrm{Ab}$ immunostaining were excluded from the analysis.

For the purposes of the study, stainings of tumor nuclei for hMLH1 and hMSH2 were evaluated as absent (no protein) or present (any evidence). Among tumors with preserved gene product, we distinguished two groups: (1) low expression $(<50 \%$ of positive cells or RS = 1 to 6), and (2) high expression ( $>50 \%$ or RS $=8$ to 12). Regarding Bax results, absence and occasional light staining $(<10 \%$ and $1+$, or RS $=0$ to 1$)$ were considered to indicate loss of gene function; low expression if 10 to $50 \%$ or RS $=2$ to 6 ; and high expression when $>50 \%$ or $\mathrm{RS}=8$ to 12 .

\section{Statistical Analysis}

Associations between the expression of the different proteins and several clinicopathologic features were calculated using the $\chi^{2}$ test. Survival curves were calculated by the Kaplan-Meier method, and log-rank tests were performed. For multivariate analysis, the Cox proportional hazards model was applied. For all calculations, SPSS-10 statistical software (SPSS Inc., Chicago, IL) was used. $P$ values of $<.05$ were considered statistically significant.

\section{RESULTS}

Endometrioid carcinomas accounted for $62 \%$ $(55 / 89)$ of the tumors, followed by carcinomas of mixed type $(22 \%$; 20/89: mucinous, $n=9$; squamous, $n=9$; serous, $n=2)$, PSC (13\%; 11/89), and MMMT (3\%; 3/89). Tumors were also classified into two groups: endometrioid type (pure endometrioid, mixed mucinous or squamous, and the MMMT due to the presence of endometrioid characteristics; $85 \% ; 75 / 89$ ) and special variants (PSC or mixed serous carcinomas; $15 \%, 13 / 89$ ).
Grade 1 was seen in $39 \%$, Grade 2 in $33 \%$, and Grade 3 in $28 \%$. Most of the patients were in low FIGO stage $(69 \%$ in I, and $17 \%$ in II), and only $12 \%$ were in III, and $2 \%$ were in IV. Patients' age was $>50$ years in 93\% (mean, 66 years).

Generally, positive immunostaining was seen for all three proteins in different proportions in the endometrium adjacent to the tumors. Regarding carcinomas, we saw loss of expression in $12.4 \%$ $(11 / 89)$ tumors for hMLH1, 1.1\% for hMSH2 (1/89), and $12.4 \%$ (11/89) for Bax (see Fig. 1 for examples). The majority of tumors showed high expression ( $>50 \%$ positive cells) of hMSH2 $(86.5 \%)$ and Bax (70\%), and there was high expression in almost half (48\%) for hMLH1. We observed occasionally weak cytoplasmic staining for hMSH2.

Because of the heterogeneous expression of these proteins within the tumors, the RS was also applied. High scores (8 to 12) were given in $68 \%$ of tumors for hMSH2, followed by Bax (28\%) and hMLH1 (19\%). There was a good correlation between the two scoring methods (all $P<.0001$ ).

Histological subtype, tumor grade, and FIGO stage correlated with each other (all $P<.001$ ). The distribution of hMLH1 and hMSH2 proteins regarding age of the patients was similar $(P=n s)$. Loss of hMLH1 expression (see Table 2) was associated with mucinous differentiation $(5 / 11 ; 45 \% ; P=.03)$. All tumors with high expression $(>50 \%$ or RS $=8$ to 12) of hMLH1 showed also high expression of hMSH2, and in one case, both proteins were negative $(P=.01)$.

Bax immunostaining was not correlated with histologic type, tumor grade, stage, or age (all $P=$ ns). Among 11 tumors with loss of Bax expression (12.5\%), 4 had also loss of hMLH1 $(4 / 11 ; 36.4 \%$; $P=$ $.017)$, and 1 had loss of hMSH2 (1/11; 9\%; $P=.037$; see Fig. 2).

Five patients developed a second malignant tumor (three breast carcinomas, one urinary bladder papillary carcinoma, and one retroperitoneal leiomyosarcoma) within a period of 2 to 5 years. Regarding the primary endometrial tumors, none had loss of hMLH1, hMSH2 or Bax expression. Low levels of hMLH1 (<50\%), and high levels $(>80 \%)$ of hMSH2 and Bax were seen in two Grade 3 tumors (MMMT and endometrioid), whose patients developed breast carcinoma. One patient with endometrioid carcinoma Grade 1 and high expression for all three proteins developed a retroperitoneal leiomyosarcoma. The tumors of the remaining two patients (with breast carcinoma and papillary carcinoma of the urinary bladder), expressed high levels of hMLH1 and hMSH2 but low levels of Bax.

The Kaplan-Meier survival analysis established strong associations between prognosis and FIGO stage $(P<.0001)$, tumor grade $(P<.0001)$, and histologic type $(P=.0036)$. Regarding hMLH1 im- 


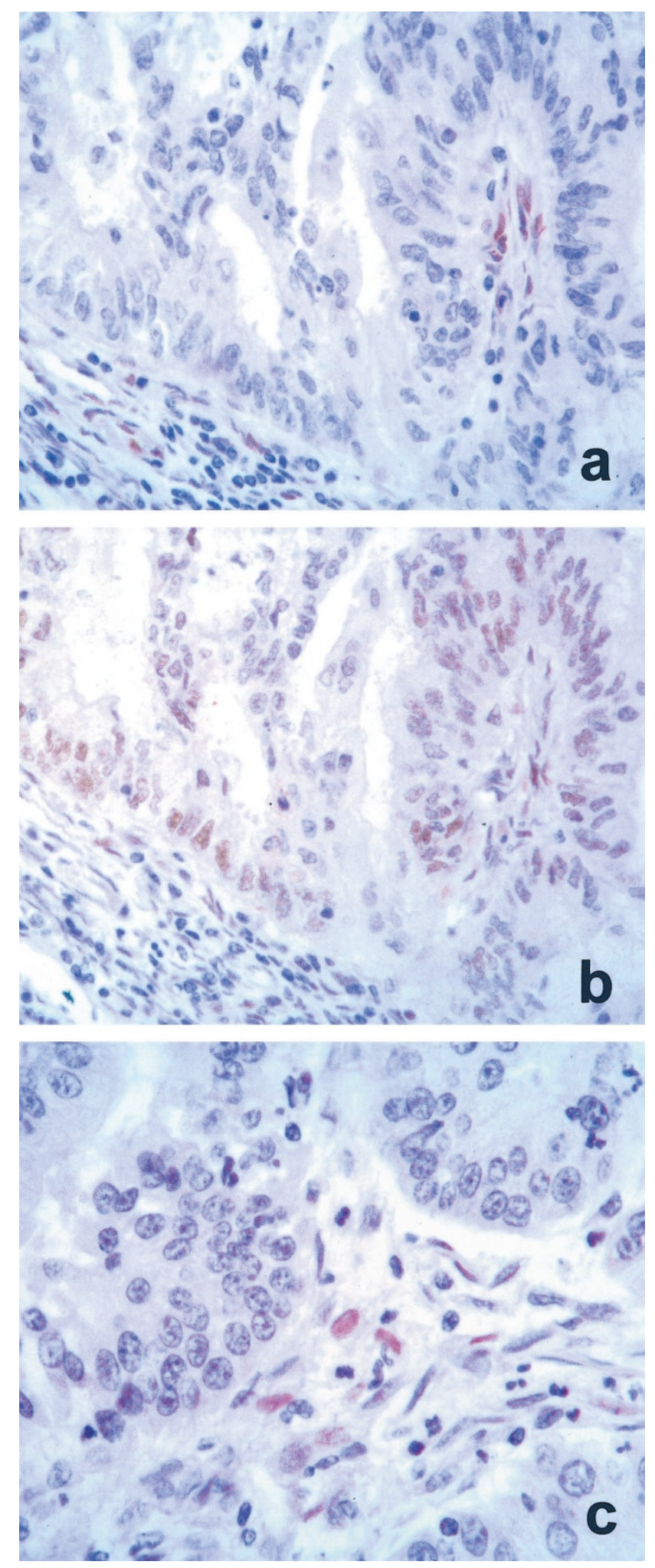

FIGURE 1. Case 18 (endometrioid carcinoma): loss of protein expression in neoplastic cells for hMLH1 (A) and Bax (B) and presence of hMSH2 (C), with scattered positivity in stroma, endothelium, and inflammatory cells throughout the tumor (original magnification, $400 \times)$.

munostaining results, we observed that patients with immunonegative tumors had higher survival rates compared with those with positive expression
TABLE 2. Characteristics of Tumors with Loss of hMLH1 Expression

\begin{tabular}{cclccll}
\hline $\begin{array}{c}\text { Case } \\
\text { No. }\end{array}$ & Age & Type & Stage & Grade & hMSH2 & Bax \\
\hline 1 & 57 & Endom & IIb & 2 & Absent & Absent \\
4 & 61 & PSC & IVa & 3 & High & High \\
18 & 61 & Mix-Muc & Ia & 2 & High & Absent \\
29 & 65 & Mix-Muc & Ia & 1 & High & High \\
39 & 68 & Endom & Ia & 2 & Low & Absent \\
42 & 54 & Mix-Muc & IIa & 1 & Low & High \\
49 & 60 & Endom & Ia & 1 & High & Absent \\
55 & 72 & Endom & IIIc & 2 & Low & High \\
62 & 71 & Mix-Muc & Ia & 1 & High & High \\
65 & 62 & Endom & Ia & 1 & High & High \\
83 & 70 & Mix-Muc & IIb & 1 & High & High \\
\hline
\end{tabular}

Endom, endometrioid carcinoma; PSC, papillary serous carcinoma; Mix-Muc, mixed mucinous carcinoma; low, protein expression of $<50 \%$ positive cells; high, protein expression of $>50 \%$ positive cells.

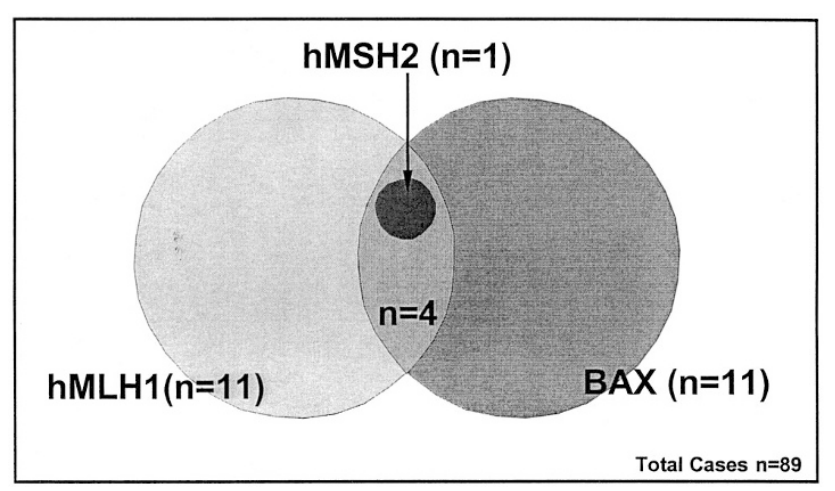

FIGURE 2. Distribution of cases with loss of hMLH1, hMSH2, and Bax protein expression.

$(P=.027$; Fig. 3$)$. A trend toward better outcome was also seen for tumors containing low levels of hMSH2 protein $(P=.08)$. Using the Cox proportional-hazards model, FIGO stage $(P<$ $.0001)$, tumor grade $(P=.001)$, histologic type $(P=$ $.001)$, and hMLH1 expression $(P=.02)$ were revealed as independent prognostic factors. Age,

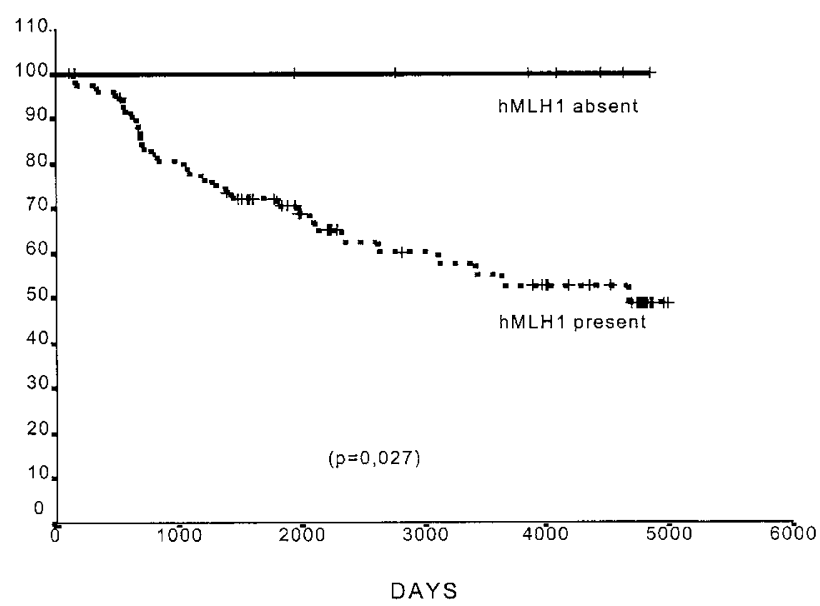

FIGURE 3. Univariate survival analysis (Kaplan-Meier) of groups with absent versus present hMLH1 protein expression (log rank test). 
hMSH2, and Bax expression did not provide significant prognostic information.

\section{DISCUSSION}

Several studies have suggested that defective MMR genes play a role in the pathogenesis of EC ( 1 , $8,15,24,25,31,39,40)$. The inability to maintain the DNA replication fidelity leads to an accumulation of errors and MSI. More recently, the availability of monoclonal $\mathrm{Ab}$ against MMR proteins has made it possible to screen for gene expression in large series of tumors $(6,8-15,18,19,23,24)$.

Based on our immunohistochemical analysis of 89 EC, it appears that in a small proportion of tumors, dysfunction of hMLH1 and Bax genes occurs. We confirmed the value of the classical prognostic factors, such as tumor grade, stage, and histologic type. Loss of expression was seen more frequently for hMLH1 than for hMSH2 (12.4\% vs. $1 \% ; 15,25,29,39)$. The preferential involvement of hMLH1 may indicate that this gene is more susceptible to somatic alterations (12).

Previous immunohistochemical analyses have shown that loss of protein expression is highly suggestive of mutations in MMR genes and that they are responsible for the MSI phenotype in some tumors $(6,9-12,18,23,24)$. However, this correlation is not perfect because a significant proportion of MSI-positive tumors do not contain any mutation $(24-26,30-39)$. In those cases, the inability to detect mutations is likely because of technical and tumor biological factors. In addition, other inactivating mechanisms in MMR genes, or mutations in genes yet unknown may be also responsible for the lack of correlation $(4,17,32)$. The high incidence of hMLH1 promoter hypermethylation found in cell lines and sporadic EC, which is strongly correlated with MSI phenotype (15, 25, 39, 41-42) and loss of protein expression, supports that this is a frequent and important mechanism by which the hMLH1 gene can be inactivated (7). This mechanism likely also inactivates other important growth regulatory genes (13-15, 25, 38, 41). Interestingly, hypermethylation of hMLH1 appears to be a phenomenon that is limited to colon and endometrium, which are most frequently affected in $\operatorname{HNPCC}(7,13,15)$.

Because the preservation of one wild-type allele is sufficient for the synthesis of the functional protein (23), loss of expression in immunohistochemical analysis may be due to biallelic inactivation secondary to mutation $(2,8,16,17)$ and/or abnormal methylation of the promoter region (41). On the other hand, protein detection does not necessarily imply normal gene function $(10,12-15)$. In fact, minor genetic alterations associated with normal levels of the protein that is inactive, without disrupting immunoreactivity, cannot be detected $(7,23,26,42)$.

Overall, MSI has been observed in about one fourth of sporadic EC, but with some variability (24-26, 29-39). For example, lower prevalence (9\%) has been found in larger series (35), and higher rates $(34 \%)$ in tumors of younger patients (29). In our study, the majority of the patients were postmenopausal, with an average age of 66 years. This may explain the small proportion of tumors with loss of hMLH1 expression.

Interestingly, absence of hMLH1 protein was commonly seen in endometrioid tumors with mucinous differentiation, and those patients had longer survival. Other series of EC have found that tumors with MSI phenotype are frequently poorly differentiated $(34,35)$ and that they show mucinous differentiation and necrosis (29). Regarding clinical outcome, conflicting results have been reported $(29,31,33,35)$ that contrast with the relatively favorable prognosis in HNPCC-associated or sporadic colorectal carcinomas $(6,22)$.

Biallelic inactivation of hMSH2 is usually due to a combination of germline and somatic mutations of the gene (13) and leads to complete absence of functional protein (23). Loss of hMSH2 expression was rare in the present study, indicating integrity of the gene in the majority of the cases. In agreement, only few hMSH2 mutations $(24,26,31,40)$, abnormal promoter methylation $(15,39)$ or absence of the protein (29), not necessarily associated with MSI phenotype, have been reported in the past. Loss of hMSH2 expression appears to be an indicator of HNPCC $(1,29)$.

Highly proliferative normal cells express hMSH2 protein $(23,27)$. Therefore, the levels in tumors might reflect their proliferative activity (28). In a series of sporadic colon carcinomas, Maeda et al. (28) reported longer survival for patients with hMSH2-negative tumors. However, in transitional cell carcinoma of the urinary bladder, reduced expression $(<20 \%)$ was seen in Grade 3 tumors, and it was associated with recurrence (20).

None of our patients who developed a second malignant tumor had loss of hMSH2 and/or hMLH1 protein expression in the primary tumors. Burks et al. (32) reported two patients with MSI-negative endometrial carcinomas, who had metachronous colorectal carcinoma. Their and our observations fail to support the idea that patients with EC showing MMR defect or MSI phenotype have an increased risk for developing second cancers.

Finally, MMR defects resulting in MSI phenotype are frequently associated with mutation of functionally important genes, such as Bax $(18,38,45,46$, 48). Generally, the incidence of both MSI and Bax mutations is lower in EC than in gastrointestinal carcinomas $(5,42)$. Frameshift mutations are found 
in 11.5 to $55 \%$ of MSI-positive EC $(25,42,48,50)$ leading to a stop codon and loss of Bax protein (45, 49).

In our series, Bax protein was observed in normal endometrial glands, stromal cells, and myometrium. Absence of staining was found in a small number of tumors (12.4\%). Interestingly, in about one third of these cases, loss of hMLH1 was also revealed, and in one case, loss of hMSH2 expression, supporting that Bax is a target gene in tumors with MMR gene defects. In the present study, Bax immunostaining did not correlate with any clinicopathological factor $(49,52)$ and did not provide prognostic information, which differs from observations in other tumor types (53-56).

In conclusion, the current study adds evidence to the notion that hMLH1 and Bax are involved in a subset of EC. Absence of hMLH1 protein appears to be associated with less aggressive clinical behavior and longer survival. However, a significant proportion of the molecular alterations in EC still remains to be identified.

Acknowledgment: We thank Mrs. A. Sendelhofert for her technical assistance.

\section{REFERENCES}

1. Lin KM, Shashidharan M, Thorson AG, Ternent CA, Blatchford GF, Christensen MA, et al. Cumulative incidence of colorectal and extracolonic cancers in MLH1 and MSH2 mutation carriers of hereditary nonpolyposis colorectal cancer. J Gastrointest Surg 1998;2:67-71.

2. Papadopoulos N, Nicolaides NC, Wei Y-F, Ruben SM, Carter KC, Rosen CA, et al. Mutation of a mutL homolog in hereditary colon cancer. Science 1994;263:1625-9.

3. Schmutte C, Marinescu RC, Copeland NG, Jenkins NA, Overhauser J, Fishel R. Refined chromosomal localization of the mismatch repair and hereditary nonpolyposis colorectal cancer genes hMSH2 and hMSH6. Cancer Res 1998;58:5023-6.

4. Liu B, Parsons R, Papadopoulos N, Nicolaides NC, Lynch HT, Watson $\mathrm{P}$, et al. Analysis of mismatch repair genes in hereditary non-polyposis colorectal cancer patients. Nat Med 1996;2:169-74.

5. Yamamoto H, Sawai H, Weber TK, Rodríguez-Bigas MA, Perucho M. Somatic frameshift mutations in DNA mismatch repair and proapoptosis genes in hereditary nonpolyposis colorectal cancer. Cancer Res 1998;58:997-1003.

6. Kim WH, Lee HW, Park SH, Kim YI, Chi JG. Microsatellite instability in young patients with colorectal cancer. Pathol Int 1998;48:586-94.

7. Herman JG, Umar A, Polyak K, Graff JR, Ahuja N, Issa JP, et al. Incidence and functional consequences of hMLH1 promoter hypermethylation in colorectal carcinoma. Proc Natl Acad Sci U S A 1998;95:6870-5.

8. Boyer JC, Umar A, Risinger JI, Lipford JR, Kane M, Yin S, et al. Microsatellite instability, mismatch repair deficiency, and genetic defects in human cancer cell lines. Cancer Res 1995; 55:6063-70.

9. Möslein G, Roche P, Goretzki P, Thibodeau SN. Protein expression of hMSH2 and hMLH1 in sporadic, familiary and hereditary colorectal tumors. Langenbecks Arch Chir Suppl Kongressbd 1997;114:109-12.

10. Thibodeau SN, French AJ, Roche PC, Cunningham JM, Tester DJ, Lindor NM, et al. Altered expression of hMSH2 and hMLH1 in tumors with microsatellite instability and genetic alterations in mismatch repair genes. Cancer Res 1996;56:4836-40.

11. Dietmaier W, Wallinger S, Bocker T, Kullmann F, Fishel R, Ruschoff J. Diagnostic microsatellite instability: definition and correlation with mismatch repair protein expression. Cancer Res 1997;57:4749-56.

12. Thibodeau SN, French AJ, Cunningham JM, Tester D, Burgart LJ, Roche PC, et al. Microsatellite instability in colorectal cancer: different mutator phenotypes and the principal involvement of hMLH1. Cancer Res 1998;58:1713-8.

13. Cunningham JM, Christensen ER, Tester DJ, Kim CY, Roche PC, Burgart LJ, et al. Hypermethylation of the hMLH1 promoter in colon cancer with microsatellite instability. Cancer Res 1998;58:3455-60.

14. Leung SY, Yuen ST, Chung LP, Chu KM, Chan AS, Ho JC. hMLH1 promoter methylation and lack of hMLH1 expression in sporadic gastric carcinomas with high-frequency microsatellite instability. Cancer Res 1999;59:159-64.

15. Kane MF, Loda M, Gaida GM, Lipman J, Mishra R, Goldman $\mathrm{H}$, et al. Methylation of the hMLH1 promoter correlates with lack of expression of hMLH1 in sporadic colon tumors and mismatch repair-defective human tumor cell lines. Cancer Res 1997;57:808-11.

16. Leach FS, Nicolaides NC, Papadopoulos N, Liu B, Jen J, Parson R, et al. Mutations of a mutS homolog in hereditary nonpolyposis colorectal cancer. Cell 1993;75:1215-25.

17. Liu B, Nicolaides NC, Markowitz S, Willson JKV, Parsons RE, Jen J, et al. Mismatch repair gene defects in sporadic colorectal cancers with microsatellite instability. Nat Genet 1995; 9:48-55.

18. Fujiwara T, Stolker JM, Watanabe T, Rashid A, Longo P, Eshleman JR, et al. Accumulated clonal genetic alterations in familial and sporadic colorectal carcinomas with widespread instability in microsatellite sequences. Am J Pathol 1998;153: 1063-78.

19. Kim H, Piao Z, Kim JW, Choi JS, Kim NK; Lee JM, et al. Expression of hMSH2 and hMLH1 in colorectal carcinomas with microsatellite instability. Pathol Res Pract 1998;194:3-9.

20. Jin TX, Furihata M, Yamasaki I, Kamada M, Liang SB, Ohtsuki Y, et al. Human mismatch repair gene (hMSH2) product expression in relation to recurrence of transitional cell carcinoma of the urinary bladder. Cancer 1999;85:478-84.

21. Fujita M, Enomoto T, Yoshino K, Nomura T, Buzard GS, Inoue M. Microsatellite instability and alterations in the hMSH2 gene in human ovarian cancer. Int J Cancer 1995; 64:361-6.

22. Ionov Y, Peinado MA, Malkhosyan S, Shibata D, Perucho M. Ubiquitous somatic mutations in simple repeated sequences reveal a new mechanism for colonic carcinogenesis. Nature 1993;363:558-61.

23. Leach FS, Polyak K, Burrell M, Johnson KA, Hill D, Dunlop MG, et al. Expression of the human mismatch repair gene hMSH2 in normal and neoplastic tissues. Cancer Res 1996; 56:235-40.

24. Katabuchi H, van Rees B, Lambers AR, Ronnett BM, Blazes MS, Leach FS, et al. Mutations in DNA mismatch repair genes are not responsible for microsatellite instability in most sporadic endometrial carcinomas. Cancer Res 1995;55: 5556-60.

25. Gurin CC, Federici MG, Kang L, Boyd J. Causes and consequences of microsatellite instability in endometrial carcinoma. Cancer Res 1999;59:462-6.

26. Lim PC, Tester D, Cliby W, Ziesmen SC, Roche PC, Hartmann L, et al. Absence of mutations in DNA mismatch repair 
genes in sporadic endometrial tumors with microsatellite instability. Cancer Res 1996;2:1907-11.

27. Wilson TM, Ewel A, Duguid JR, Eble JN, Lescoe MK, Fishel R, et al. Differential cellular expression of the human MSH2 repair enzyme in small and large intestine. Cancer Res 1995; 55:5146-50.

28. Maeda K, Nishiguchi Y, Onoda N, Otani H, Nakata B, Yamada S, et al. Expression of the mismatch repair gene hMSH2 in sporadic colorectal cancer. Int J Oncol 1998;13: 1147-51.

29. Parc YR, Halling KC, Burgart LJ, McDonnell SK, Schaid DJ, Thibodeau SN, et al. Microsatellite instability and hMLH1/ hMSH2 expression in young endometrial carcinoma patients: associations with family history and histopathology. Int J Cancer 2000;86:60-6.

30. Peltomäki P, Lothe RA, Aaltonen LA, Pylkkänen L, NyströmLahti M, Seruca R, et al. Microsatellite instability is associated with tumors that characterize the hereditary nonpolyposis colorectal carcinoma syndrome. Cancer Res 1993; 53:5853-5.

31. Risinger JI, Berchuck A, Kohler MF, Watson P, Lynch HT, Boyd J. Genetic instability of microsatellites in endometrial carcinoma. Cancer Res 1993;53:5100-3.

32. Burks R, Kessis TD, Cho KR, Hedrick L. Microsatellite instability in endometrial carcinoma. Oncogene 1994;9:1163-6.

33. Duggan BD, Felix JC, Muderspach LI, Tourgeman D, Zheng J, Shibata D. Microsatellite instability in sporadic endometrial carcinoma. J Natl Cancer Inst 1994;86:1216-21.

34. Kobayashi K, Sagae S, Kudo R, Saito H, Koi S, Nakamura Y. Microsatellite instability in endometrial carcinomas: frequent replication errors in tumors of early onset and/or of poorly differentiated type. Genes Chromosom Cancer 1995; 14:128-32.

35. Caduff RF, Johnston CM, Svoboda-Newman SM, Poy EL, Merajver SD, Frank TS. Clinical and pathological significance of microsatellite instability in sporadic endometrial carcinoma. Am J Pathol 1996;148:1671-8.

36. Kowalski LD, Mutch DG, Herzog TJ, Rader JS, Goodfellow PJ. Mutational analysis of MLH1 and MSH2 in 25 prospectivelyacquired RER+ endometrial cancers. Genes Chromosom Cancer 1997;18:219-27.

37. Mutter GL, Boynton KA, Faquin WC, Ruíz RE, Jovanovic AS. Allelotype mapping of unstable microsatellites establishes direct lineage continuity between endometrial precancers and cancer. Cancer Res 1996;56:4483-6.

38. Catasús L, Machín P, Matías-Guiu X, Prat J. Microsatellite instability in endometrial carcinomas: clinicopathologic correlations in a series of 42 cases. Hum Pathol 1998;29:1160-4.

39. Esteller M, Levine R, Baylin SB, Ellenson LH, Herman JG. MLH1 promoter hypermethylation is associated with the microsatellite instability phenotype in sporadic endometrial carcinomas. Oncogene 1998;16:2413-7.

40. Umar A, Boyer J, Thomas C, Nguyen DC, Risinger JI, Boyd J, et al. Defective mismatch repair in extracts of colorectal and endometrial cancer cell lines exhibiting microsatellite instability. J Biol Chem 1994;269:14367-70.

41. Esteller M, Catasús L, Matías-Guiu X, Mutter GL, Prat J, Baylin SB, Herman JG. hMLH1 promoter hypermethylation is an early event in human endometrial tumorigenesis. Am J Pathol 1999;155:1767-72.

42. Schwartz S Jr, Yamamoto $H$, Navarro $M$, Maestro $M$, Reventós J, Perucho M. Frameshift mutations at mononucleotide repeats in caspase-5 and other target genes in endometrial and gastrointestinal cancer of the microsatellite mutator phenotype. Cancer Res 1999;59:2995-3002.

43. Kang GH, Shim YH, Ro JY. Correlation of methylation of the hMLH1 promoter with lack of expression of hMLH1 in sporadic gastric carcinomas with replication error. Lab Invest 1999;79:903-9.
44. Chung YJ, Park SW, Song JM, Lee KY, Seo EJ, Choi SW, et al. Evidence of genetic progression in human gastric carcinomas with microsatellite instability. Oncogene 1997;15:171926.

45. Rampino N, Yamamoto H, Ionov Y, Li Y, Sawai H, Reed JC, Perucho M. Somatic frameshift mutations in the BAX gene in colon cancers of the microsatellite mutator phenotype. Science 1997;275:967-9.

46. Yagi OK, Akiyama Y, Nomizu T, Iwama T, Endo M, Yuasa Y. Proapoptotic gene BAX is frequently mutated in hereditary nonpolyposis colorectal cancers but not in adenomas. Gastroenterology 1998;114:268-74.

47. Ottini L, Falchetti M, D’Amico C, Amorosi A, Saieva C, Masala G, et al. Mutations at coding mononucleotide repeats in gastric cancer with the microsatellite mutator phenotype. Oncogene 1998;16:2767-72.

48. Ouyang H, Furukawa T, Abe T, Kato Y, Horii A. The BAX gene, the promoter of apoptosis, is mutated in genetically unstable cancers of the colorectum, stomach, and endometrium. Clin Cancer Res 1998;4:1071-4.

49. Catasús L, Matías-Guiu X, Machín P, Muñoz J, Prat J. BAX somatic frameshift mutations in endometrioid adenocarcinomas of the endometrium: evidence for a tumor progression role in endometrial carcinomas with microsatellite instability. Lab Invest 1998;78:1439-44.

50. Catasús L, Matías-Guiu X, Machín P, Zannoni GF, Scambia G, Benedetti-Panicci P, et al. Frameshift mutations at coding mononucleotide repeat microsatellites in endometrial carcinoma with microsatellite instability. Cancer 2000;88:2290-7.

51. Oltvai Z, Milliman C, Korsmeyer SJ. Bcl2 heterodimerizes in vivo with a conserved homolog, Bax, that accelerates programmed cell death. Cell 1993;74:609-19.

52. Koshida Y, Saegusa M, Okayasu I. Apoptosis, cell proliferation and expression of $\mathrm{Bcl} 2$ and Bax in gastric carcinomas: immunohistochemical and clinicopathological study. Br J Cancer 1997;75:367-73.

53. Jackel MC, Dorudian MA, Marx D, Brinck U, Schauer A, Steiner W. Spontaneous apoptosis in laryngeal squamous cell carcinoma is independent of bcl-2 and bax protein expression. Cancer 1999;85:591-9.

54. Krajewska M, Krajewski S, Epstein JI, Shabaik A, Sauvageot J, Song $\mathrm{K}$, et al. Immunohistochemical analysis of bcl2, bax, bcl-X, and mcll expression in prostate cancers. Am J Pathol 1996;148:1567-76.

55. Sjöstrom J, Krajewski S, Franssila K, Niskanen E, Wasenius VM, Nordling S, et al. A multivariate analysis of tumour biological factors predicting response to cytotoxic treatment in advanced breast cancer. Br J Cancer 1998;78:812-5.

56. Tai YT, Lee S, Niloff E, Weisman C, Strobel T, Cannistra SA. BAX protein expression and clinical outcome in epithelial ovarian cancer. J Clin Oncol 1998;16:2583-90.

57. Wehrli BM, Krajewski S, Gascoyne RD, Reed JC, Gilks CB. Immunohistochemical analysis of bcl2, bax, mcll, and bcl-X expression in ovarian surface epithelial tumors. Int J Gynecol Pathol 1998;17:255-60.

58. Scully RE, Bonfiglio TA, Kurman RJ, Silverberg SG, Wilkinson EJ. WHO. Histological typing of female genital tract tumors. 2nd ed. Heidelberg, Germany: Springer-Verlag; 1994. p. 13-8.

59. Kurman RJ, Zaino RJ, Norris HJ. Endometrial carcinoma. In: Kurman RJ, editor. Blaustein's pathology of the female genital tract. 4th ed. New York: Springer-Verlag; 1994. p. 441.

60. Announcements: FIGO stages-1988 revision. Gynecol Oncol 1989;35:125-7.

61. Remmele W, Stegner HE. Vorschlag zur einheitlichen Definition eines Immunreaktiven Score (IRS) für den Immunhistochemischen Oestrogen Rezeptor-nachweis (ER-ICA) im mammakarzinomgewebe. Pathologe 1987;8:138-40. 